\title{
Comparative Study of Mechanical and Electronic Paddy Planter for Direct Seeding
}

\author{
P. Rajaiah*, Indra Mani, Adarsh Kumar, Satish D. Lande, Roaf A. Parray, \\ Ashok Kumar Singh and Cini Vergese
}

ICAR-Indian Agricultural Research Institute, New Delhi - 110012, India

*Corresponding author

\begin{tabular}{|c|}
\hline Keywords \\
\hline $\begin{array}{l}\text { Electronic and } \\
\text { mechanical planter, Seed } \\
\text { rate, Spacing, Seed } \\
\text { placement index, } \\
\text { Comparison }\end{array}$ \\
\hline Article Info \\
\hline $\begin{array}{l}\text { Accepted: } \\
\text { 10 August } 2018 \\
\text { Available Online: } \\
\text { 10 September } 2018\end{array}$ \\
\hline
\end{tabular}

\section{A B S T R A C T}

The study was under taken to design and develop a mechanical and electronic precision planter for paddy direct seeding and compared for optimum seed rate, germination, seed placement index and spacing. The comparison o of two methods was done in terms of seed rate, spacing and seed placement index The observe seed rate, spacing and seed placement index values of mechanical and electronic methods were $22.7 \mathrm{~kg} / \mathrm{ha}, 14.4 \mathrm{~cm}$ and $74.3 \%$ and $19.97 \mathrm{~kg} / \mathrm{ha}, 14.8 \mathrm{~cm}$ and $86.39 \%$, respectively. A saving of $12.04 \%$, in seed rate was observed by sowing with electronic metering method over mechanical. The variation in spacing was less than $4.0 \%$ as compared to mechanical method of sowing. The seed placement index was found to increase by $16.3 \%$ with electronic metering. Thus based on the results of seed rate, spacing and seed placement index, it is imperative to say that electronic metering leads to better precision as compared to mechanical sowing. The Seed Placement Index (SPI) and percentage of one and two seeds per hill, increased up to a forward speed of $2.0 \mathrm{~km} / \mathrm{h}$ and $35^{\circ}$ angle of inclination and thereafter decreased significantly. The breakeven point and payback period of developed precision planter was $95 \mathrm{~h} /$ year and 2.5 years respectively; very close to that of mechanical planter for which the values were $88 \mathrm{~h}$ /year \& 2.3 years respectively.

\section{Introduction}

Rice (Oryza sativa), the world's most important crop, is a staple food for more than half of the world's population. Rice ranks third after wheat and maize in terms of worldwide production. About $90 \%$ of the world's rice (146.7 million ha of area with a production of 673.6 million tons of paddy) is grown and produced in Asia. Worldwide, rice is grown on 163 million hectares, with an annual production of about 750 million tons (FAO, 2015).

Precision seeding of crop is paramount importance to achieve reduced seed rate, good crop geometry, and poor seed placement and sound crop stand. The manual application of seed, without suitable machines, fails to achieve the goals of proper seeding and increased cost of cultivation. Design of a precision planter needs optimization of 
different design parameters including crop, soil and machine.

The manual transplanting of rice has a very high demand of manual labour of 360 man$\mathrm{h} / \mathrm{ha}$. In addition, it is estimated that transplanted rice needs about 3000-5000 liters of water to produce one $\mathrm{kg}$ of rice grain which is 3 to 5 times more than for other cereals like wheat, corn etc. At global level 70-80 per cent of fresh water is used in agriculture and rice accounts for 85 per cent of this water (Pathak, et al., 2011). Puddling and transplanting operations consume about $30 \%$ of total water availability of rice.

Direct seeded rice removes puddling, drudgery of transplanting and saving of water. The success of DSR mainly attributed to, timely sowing, reduced cost of cultivation, seed rate, fertilizer, water and equal or higher yield as compared to transplanting (Mahajan, et al., 2005). DSR is currently being practiced in China, Malaysia, Thailand, Vietnam, Philippines, and Sri Lanka. About $95 \%$ of the rice grown in Sri Lanka is direct-seeded (wetand dry-seeding) (Pandey and Velasco 2002; Weerakoon et al., 2011). In fact, Globally China contributing more than $28 \%$ of total rice production (FAOS 2011). The area under DSR is increasing in China very rapidly and presently increased to 28 per cent.

Traditionally, direct sowing of rice behind country plough or bullock operated methods have been practiced which required high seed rate, involved drudgery, consumed more time per unit area and placed the seed un even in the field. In some parts of the country, farmers have been using multicrop seed drill fitted with fluted roller or inclined metering mechanism driven by ground wheel. These locally developed seed drills or planters have no scientific design and have not been evaluated for performance as per standard. Problems identified with existing seed drills are unequal seed placement in a row, excessive seed dropping, strucking of ground wheel in sticky soils and ground wheel slip/skid in loose soils (Srigiri et al., 2013).

Design of an appropriate precision planter by incorporating precision seed metering system to reduce seed rates, missing hills and maintain the uniformity of crop spacing was felt need of the hour. This would boost direct seeded rice mechanization system. Thus design and development of a precision planter which place a single seed at pre- determined depth and to maintain seed to seed and row spacing.

Srivastava and Panwar (1985) developed a drill for sowing pre-germinated rice consisting of a hopper, metering unit, furrow openers, ground wheels, float and the basic frame with controls. Three sprout lengths of 2, 4 and 6.5 $\mathrm{mm}$ with seed rate 45,50 and $55 \mathrm{~kg} / \mathrm{ha}$ were used in the field to see the effect on yield. It was observed that a sprout length of $2-5 \mathrm{~mm}$ found to be optimum for maximum plant population and grain yield. Experiments were conducted on light sandy loam soils and paddy variety 'Pusa 33' was used. Field performance specification are $11.2 \mathrm{~kg}$ draught, $0.08 \mathrm{hah}^{-1}$ field capacity, 72.8 per cent field efficiency, $52.4 \mathrm{~kg} \mathrm{ha}^{-1}$ seed rate, 92 per cent plant emergence and 2.32 tha $^{-1}$ crop yield.

Sahoo et al., (1994) developed a six row power tiller operated pre-germinated paddy seeder and results showed that the effective field capacity of this seeder was 0.168 and $0.114 \mathrm{ha} \mathrm{h}^{-1}$ for 99 and $253 \mathrm{~mm}$ hard pan depths respectively. The row to row spacing was $200 \mathrm{~mm}$ and hill to hill spacing was 99.5 mm with 3-5 seeds per hill. Cup type seed metering discs of $8 \mathrm{~mm}$ diameter and $6 \mathrm{~mm}$ depth were designed so as to pick up 3-5 seeds per hill. The capacity of the hopper was $40 \mathrm{~kg}$. The cost of operation of the seeder was observed Rs. 173 per hectare. The seed rate 
was set at 75 to $85 \mathrm{~kg} / \mathrm{ha}$ for three varieties, super fine, fine and coarse grain.

Meena (2005) developed an electronically assisted seed metering mechanism. Metering mechanism consisted of electronic circuit which regulated a stepper motor.

The seed carried by belt in its cell was supported from below by plate. Stepper motor was used to drive the belt. Stepper motor was driven through a control circuit. Proximity sensor was used on the ground wheel spacing along with a plate to achieve the desired spacing at which seeds are to be sown.

Singh and Mane (2011) developed an electronic metering mechanism with an attempt to make the drills/planters simpler without compromising precision in seed placement for okra seed by using cup type seed metering unit. It was observed that at 15 target seed spacing, were 15.3, 15.2 and 15.3 $\mathrm{cm}$, respectively at forward speeds of 1.0, 1.5 and $1.85 \mathrm{kmph}$ respectively. Similarly at 30 $\mathrm{cm}$ target seed spacing, the observed seed spacings were, $30.4,30.8,31$ and $30.9 \mathrm{~cm}$ respectively at 1.0, 2.0, 2.5 and $2.75 \mathrm{kmph}$ forward speeds respectively. At $15 \mathrm{~cm}$ target spacing the number of seeds per meter length varied between 5 and 7 with average of 6 seeds for all levels of forward speeds.

\section{Materials and Methods}

\section{Development of prototype paddy planters}

A tractor drawn prototype paddy planter was developed based on the optimized levels of variables for selected paddy varieties (Singh, 1984; Shrivastava et al., 2003 and Isaac Bamgboye et al., 2006). The prototype essentially consisted of a main frame, inclined plate seed metering unit, power transmission system, furrow opener and seed covering device. The planter was designed to plant nine rows at row spacing of $0.20 \mathrm{~m}$ covering a total width of $1.8 \mathrm{~m}$.

\section{Main frame}

The mainframe of the unit $(2000 \times 700 \times 1080$ $\mathrm{mm}$ ) was fabricated using a mild steel channel section of size $50 \times 50 \times 5 \mathrm{~mm}$. The seed metering units with individual seed boxes were mounted on the sub main frame of size $40 \times 40 \times 3 \mathrm{~mm} \mathrm{~L}$ angle. Three point hitch assembly was provided in the front position of the main frame to hitch the planter with the tractor.

\section{Seed metering unit}

The inclined plate planter consisted of nine seed metering units fitted on the sub main frame. Each unit consisted of a seed hopper, inclined plate seed metering plate and transmission system. The seed metering plate was fabricated using $3 \mathrm{~mm}$ thickness and 170 $\mathrm{mm}$ diameter nylon sheet. Each seed metering plate has 18 numbers of cells.

\section{Seed hopper}

The seed hopper was semi cylindrical in shape and seed separator plate with opening near metering plate so that the large portion is for holding bulk paddy seeds and the smaller for holding the seeds to be metered. Modular type seed boxes were developed for each seed metering plate.All the nine seed metering units were mounted on the main frame. The face of the seed hopper was kept at an inclination of $40^{\circ}$ to the horizontal (more that the angle of repose of paddy seeds $35^{\circ}$ ) to ensure free flow of seeds inside the hopper. The desired seed spacing of any planter mainly depend on height of metering device from the ground level. The seed metering unit was kept at a minimum height of $500 \mathrm{~mm}$ from the furrow to obtain precision placement of seeds (Wanjura and Hudspeth, 1969). 


\section{Seed tube}

The seed tube of $25 \mathrm{~mm}$ diameter was fixed to the seed delivery chute. The height of tube was $500 \mathrm{~mm}$ and kept at an angle $\mathrm{f} 18^{\circ}$ to the vertical (RNAM, 1991). The velocity of seed at the end of tube should be low to minimize bouncing and rolling of seeds in the furrow.

\section{Power transmission system}

The power was transmitted from the ground wheel shaft to an intermediate shaft fitted below the main frame through chain and sprocket transmission with speed ratio of 1:0.5. The intermediate drive shaft got its support from the main frame with necessary support arms.

\section{Power transmission system of electronic metering planter}

The power transmission system for seed metering comprised of DC motor, Microcontroller unit, 16 X 2 char LCD, Pulse Width Modulator (PWM) and Inductive Proximity Sensor. The selection of dc motor was done based on the torque required by the feed shaft of the planter.

The torque required by the 9 row planter was determined by using a torque sensor in the laboratory. A handle was fixed on the feed shaft of the planter and rotated by hand (Fig. 1 and 2). The minimum and maximum torque requirement was noted with and without load.

This procedure was followed for three replications. The minimum torque observed was $6 \mathrm{~N}-\mathrm{m}$ without load and maximum was 10 $\mathrm{N}-\mathrm{m}$ with load. The average torque requirement was found to be $8 \mathrm{~N}-\mathrm{m}$ and considering the factor of safety 4 , the final torque estimated was $32 \mathrm{~N}-\mathrm{m}$. Hence, a $40 \mathrm{~N}$ $\mathrm{m}$ torque with $60 \mathrm{rpm}$ and $150 \mathrm{~W}$ DC motor was selected for the seed metering unit.

\section{Working operation of electronic metering system}

A spiked wheel with 8 spikes at every 45 degree was used for sensing the rpm of the front wheel of the tractor. A timer feature inside the MCU monitored the timings. As the sensor sensed the spike, it sent a pulse to this MCU which further started the timer till the next spike was sensed. If the next spike was not sensed within a particular period of time, the rpm was set to zero and the motor PWM was also set to zero.

Now the time average for either 2,4 or 8 spikes was taken depending on the speed of rotation of the wheel i.e. if the wheel was rotating slowly, take 2 average values were taken, if it was moving at a high speed, then 8 averages were taken. These averages ensured accurate values of rpm. Further, the speed of the wheel was calculated by dividing the circumference i.e. the distance travelled in one round by the rpm, i.e. time for one revolution. These values were displayed on the LCD and the same values were fed to the dc motor through PWM (Fig. 1).

\section{Furrow opener and seed covering device}

An inverted-T type furrow opener fitted below the main frame in the front portion of each seed metering unit were provided to open the furrow.

\section{Hydraulic jack}

A hydraulic jack of 3 tones capacity was provided on rear side of the main frame to change the angle of inclination of seed metering plate.

\section{Angle meter}

An angle meter graduated from 0 to 180 degrees was provided on the seed hopper 
frame to read or set the angle of inclination of hopper. The specifications of the mechanical and electronic planter are given in Table 1.

\section{Seed placement index (SPI)}

For DSR cultivation in order to achieve the desired seed rate of paddy, the number of seeds per hill recommended shall be a minimum of one and maximum of two.

Hence, the measured values of percentage of hills with two seeds, percentage of hills with one seed, percentage of hills with more than two seeds and percentage of missing hills, the seed placement index (SPI) was calculated by using the following expression (Kachman and Smith, 1995).

Per cent hills having (one seed + two seeds) SPI = ------------------------------------ x 100

Per cent hills having (one seed + two seeds + no seed $+>$ two seeds)

\section{Seed rate}

The seed rate was calculated for all the treatments by measuring the difference in weight of seeds prior and after sowing and compared.

\section{Cost economics}

The total cost of planting was determined based on fixed cost and variable cost and accordingly breakeven point and payback period were estimated (IS standard IS: 91641979).

\section{Breakeven point}

The breakeven point is the point at which the gains equal to the losses.

A break -even point defines when an investment will generate a positive return.

\section{Results and Discussion}

The performance of developed prototype precision paddy planters evaluated in the field with and without electronic seed metering to receive the data for comparative analysis (Fig. 3 ). The performance of the prototype was evaluated in terms of seed placement index and distribution of seed count per hill, plant spacing, number of plants $/ \mathrm{m}^{2}$, and germination percentage and seed rate using PUSA-1121 paddy variety.

\section{Seed placement index (SPI)}

For mechanical planter, it was observed that the highest SPI value of $82.08 \%$ was observed at a forward speed of $2.0 \mathrm{~km} / \mathrm{h}$ and inclination of 35 degrees and lowest value was observed $70.64 \%$ at $2.5 \mathrm{~km} / \mathrm{h}$ and 40 degrees (Table 2).

The seed placement index increased from 76.78 to $79.4 \%$ as the forward speed increased from 1.5 to $2.0 \mathrm{~km} / \mathrm{h}$. Further increase of speed resulted decrease of SPI to 73.8 per cent, whereas for electronic planter, it was observed that the highest SPI value of $92.81 \%$ was observed at a forward speed of $2.0 \mathrm{~km} / \mathrm{h}$ and inclination of 35 degrees and lowest value was observed $79.36 \%$ at $2.5 \mathrm{~km} / \mathrm{h}$ and 30 degrees. The seed placement index increased from 87.57 to $89.1 \%$ as the forward speed increased from 1.5 to $2.0 \mathrm{~km} / \mathrm{h}$. Further increase of speed resulted decrease of SPI to 82.43 per cent (Table 2).

\section{Seed spacing}

For mechanical planter, it was observed that the lowest and highest spacing value of 13.17 $\mathrm{cm}$ and $17.43 \mathrm{~cm}$ observed at forward speeds 1.5 and $2.5 \mathrm{~km} / \mathrm{h}$ and inclinations of 30 and 40 degrees respectively. The spacing of $14.43 \mathrm{~cm}$ near to the recommended spacing for paddy $(15 \mathrm{~cm})$ was observed at a forward speed of 2.0 $\mathrm{km} / \mathrm{h}$ and inclination of 35 degrees. 
Fig.1 Electronic prototype planter components

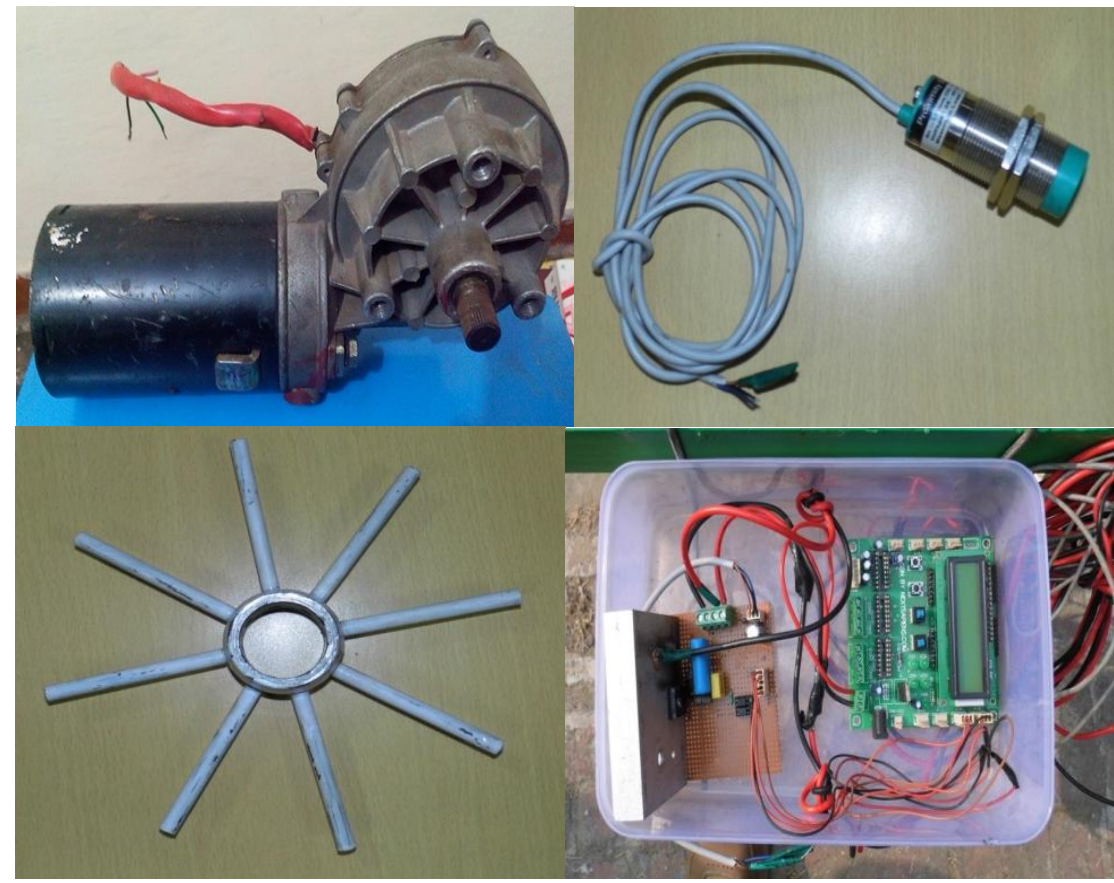

Fig.2 Mechanical and Electronic prototype precision paddy planters
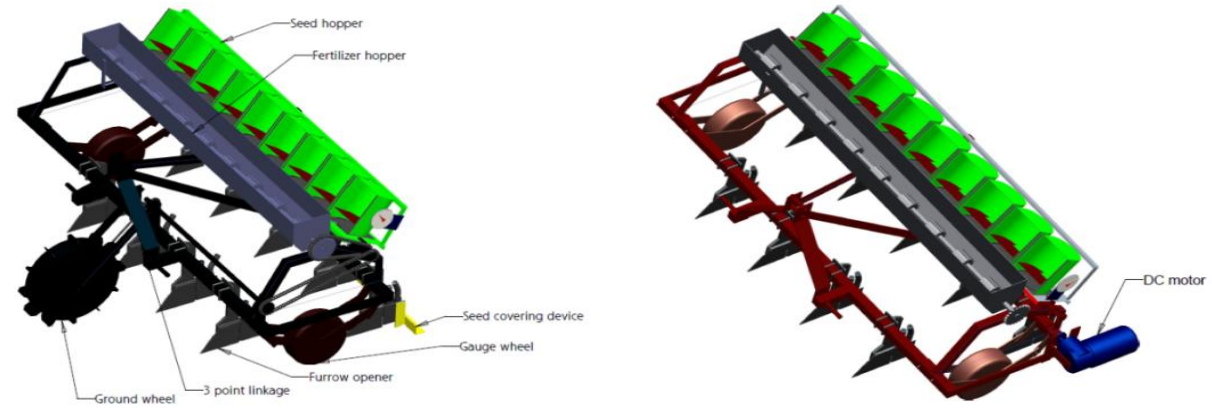

Fig.3 Field operation of mechanical and electronic paddy planter

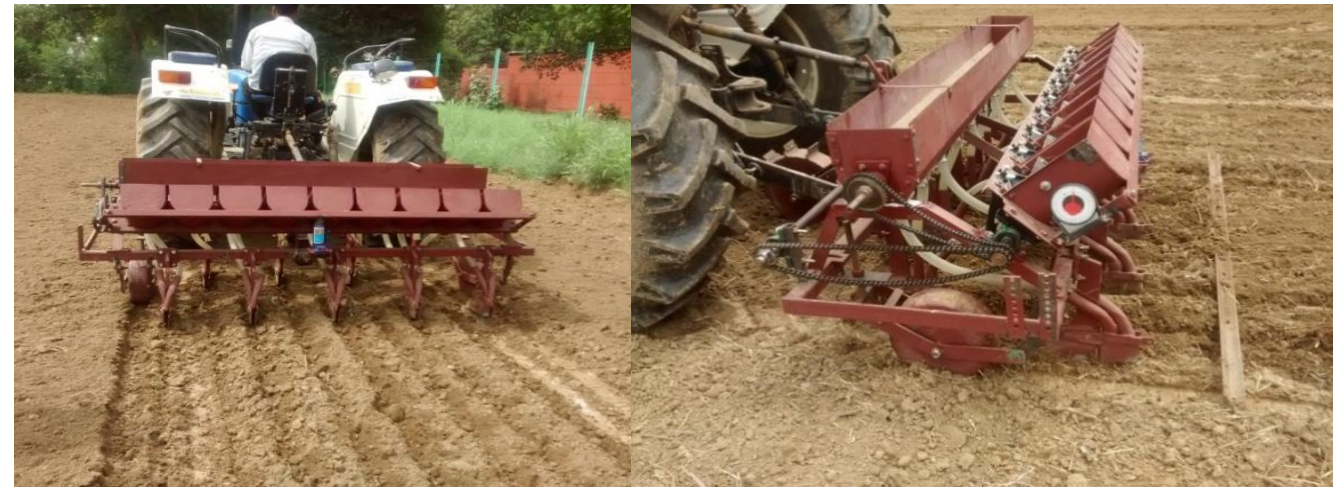




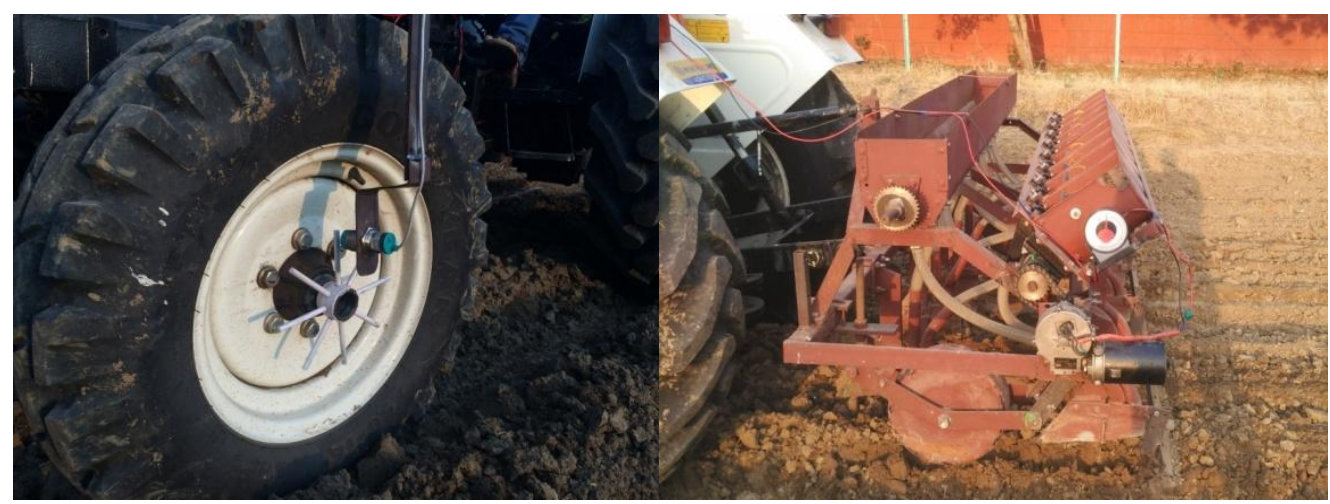

Table.1 Specifications of prototype mechanical and electronic precision paddy planter

\begin{tabular}{|c|c|c|c|}
\hline \multirow{2}{*}{$\begin{array}{l}\text { S. } \\
\text { No. }\end{array}$} & \multirow[t]{2}{*}{ Item } & \multicolumn{2}{|c|}{ Values } \\
\hline & & Mechanical & Electronic \\
\hline$\overline{\mathbf{A}}$ & Over all dimensions (L X B X H), mm & $1800 x 1420$ x 1080 & $\begin{array}{l}1800 x 1420 x \\
1080\end{array}$ \\
\hline $\mathbf{B}$ & Seed metering unit & & \\
\hline $\mathbf{I}$ & Type of seed metering mechanism & Inclined plate & Inclined plate \\
\hline Ii & Number & 9 & 9 \\
\hline Iii & Shape of seed hopper & Semi Cylindrical & Semi Cylindrical \\
\hline$\overline{\mathbf{I v}}$ & Diameter of seed metering plate, $\mathrm{mm}$ & 170 & 170 \\
\hline $\mathbf{V}$ & Number of cells in seed metering plate & 18 & 18 \\
\hline $\mathbf{V i}$ & Inclination of seed metering plate & $35 \mathrm{deg}$ & $35 \mathrm{deg}$ \\
\hline Vii & $\begin{array}{l}\text { Peripheral speed of seed metering plate, } \\
\mathrm{kmph}^{-1}\end{array}$ & 2 & 2 \\
\hline $\mathbf{C}$ & Ground wheel & & DC Motor \\
\hline $\mathbf{I}$ & Type & Spike toothed wheel & Wiper \\
\hline Ii & Effective diameter of ground wheel, mm & 350 & PWM \\
\hline Iii & Number of spikes & 12 & Proximity Sensor \\
\hline $\mathbf{D}$ & Furrow opener & & \\
\hline $\mathbf{I}$ & Number of furrow openers & 9 & 9 \\
\hline$\overline{\text { Ii }}$ & Type of furrow opener & Inverted T-type & Inverted T-type \\
\hline$\overline{\mathbf{E}}$ & Furrow closer & & \\
\hline $\bar{I}$ & Number of furrow closers & 1 & 1 \\
\hline Ii & Type of furrow closers & Flat type & Flat type \\
\hline $\mathbf{F}$ & Power transmission & & \\
\hline$\overline{\mathbf{I}}$ & Type & $\begin{array}{l}\text { Bevel gear, } \\
\text { chain and sprocket } \\
\text { transmission }\end{array}$ & Electronic \\
\hline
\end{tabular}


Table.2 Effect of forward speed and inclination on number of seeds per drop on percentage of seeds per drop

\begin{tabular}{|c|c|c|}
\hline $\begin{array}{c}\text { Forward } \\
\text { Speed }(\mathbf{k m} / \mathbf{h})\end{array}$ & $\begin{array}{c}\text { Mechanical Planter } \\
\text { Seed placement index }\end{array}$ & $\begin{array}{c}\text { Electronic Planter } \\
\text { Seed placement index }\end{array}$ \\
\hline 1.5 & 76.78 & 87.57 \\
\hline 2 & 79.40 & 89.10 \\
\hline 2.5 & 73.80 & 82.43 \\
\hline Mean & 76.66 & 86.37 \\
\hline Inclination & & \\
\hline 30 & 75.57 & 84.49 \\
\hline 35 & 79.27 & 88.37 \\
\hline 40 & 75.14 & 86.24 \\
\hline Mean & 76.66 & 86.37 \\
\hline
\end{tabular}

Table.3 Effect of selected levels of forward speed and seed metering plate inclination on spacing

\begin{tabular}{|c|}
\hline $\begin{array}{c}\text { Forward } \\
\text { speed } \\
(\mathbf{k m} / \mathbf{h})\end{array}$ \\
\hline 1.5 \\
\hline 2 \\
\hline 2.5 \\
\hline CV \\
\hline
\end{tabular}

\begin{tabular}{|c|c|c|}
\hline \multicolumn{3}{|c|}{ Mechanical Planter } \\
\hline \multicolumn{3}{|c|}{ Mean spacing, cm } \\
\hline $30^{\circ}$ & $35^{\circ}$ & $40^{\circ}$ \\
\hline 13.17 & 14.20 & 16.23 \\
\hline 14.00 & 14.43 & 17.13 \\
\hline 15.83 & 16.20 & 17.43 \\
\hline 9.52 & 7.32 & 3.69 \\
\hline
\end{tabular}

\begin{tabular}{|c|c|c|}
\hline \multicolumn{3}{|c|}{ Electronic Planter } \\
\hline $30^{\circ}$ & $35^{\circ}$ & $40^{\circ}$ \\
\hline 13.85 & 13.97 & 14.15 \\
\hline 14.3 & 14.80 & 15.75 \\
\hline 16.08 & 16.42 & 16.52 \\
\hline 7.55 & 8.09 & 8.13 \\
\hline
\end{tabular}

Table.4 Effect of selected levels of forward speed and seed metering plate Inclination on germination

\begin{tabular}{|c|c|c|c|c|c|c|}
\hline \multirow{2}{*}{$\begin{array}{c}\text { Forward } \\
\text { speed }\end{array}$} & \multicolumn{3}{|c|}{ Mechanical Planter } & \multicolumn{3}{c|}{ Electronic Planter } \\
\hline $\mathbf{k m} / \mathbf{h})$ & \multicolumn{3}{|c|}{ Germination (\%) } & \multicolumn{3}{c|}{ Germination (\%) } \\
\hline 1.5 & $30^{\circ}$ & $35^{\circ}$ & $40^{\circ}$ & $30^{\circ}$ & $35^{\circ}$ & $40^{\circ}$ \\
\hline 2 & 95.89 & 96.20 & 96.05 & 95.48 & 96.50 & 93.10 \\
\hline 2.5 & 94.03 & 95.89 & 93.33 & 94.63 & 96.24 & 94.33 \\
\hline CV & 91.41 & 91.26 & 88 & 92.40 & 94.06 & 91.80 \\
\hline & 2.40 & 2.93 & 4.43 & 1.7 & 1.4 & 1.4 \\
\hline
\end{tabular}

Table.5 Effect of forward speed and seed metering plate inclination of on seed rate

\begin{tabular}{|c|c|c|c|c|c|c|}
\hline \multirow{2}{*}{$\begin{array}{c}\text { Forward } \\
\text { speed }(\mathrm{km} / \mathrm{h})\end{array}$} & \multicolumn{3}{|c|}{ Mechanical Planter } & \multicolumn{3}{c|}{ Electronic Planter } \\
\cline { 2 - 7 } & $30^{\circ}$ & $35^{\circ}$ & $40^{\circ}$ & $30^{\circ}$ & $35^{\circ}$ & $40^{\circ}$ \\
\hline 1.5 & 22.10 & 22.38 & 22.80 & 19.10 & 20.60 & 21 \\
\hline 2 & 21.50 & 22.17 & 22.75 & 18.90 & 20.17 & 20.85 \\
\hline 2.5 & 22.77 & 23.67 & 24.20 & 20.25 & 21.50 & 22.20 \\
\hline CV & 2.86 & 3.57 & 3.54 & 3.75 & 3.27 & 3.47 \\
\hline
\end{tabular}


Table.6 Average values of seed rate, spacing and seed placement index of two methods

\begin{tabular}{|l|c|c|c|}
\hline Sowing method & Seed rate(kg/ha) & Spacing (cm) & SPI (\%) \\
\hline Mechanical & 22.70 & 14.4037 & 74.28 \\
\hline Electronic & 19.97 & 14.80 & 86.39 \\
\hline
\end{tabular}

Table.7 Cost economics of developed prototype planter

\begin{tabular}{|l|c|c|}
\hline \multicolumn{1}{|c|}{ Prototype machine } & Mechanical & Electronic \\
\hline Cost of prototype, Rs. & 54,262 & 79,262 \\
\hline Hourly cost of operation, Rs. & 585 & 616 \\
\hline Break even point & $43 \%$ of annual utility of $200 \mathrm{~h}$ & $47.6 \%$ of annual utility of 200 hours \\
\hline Pay back period, year & 2.3 & 2.5 \\
\hline
\end{tabular}

Whereas for electronic planter, it was observed that the spacing data at selected variables is presented (Table 3). A spacing of 14.8 was observed at optimum forward speed of $2.0 \mathrm{~km} / \mathrm{h}$ and inclination of 35 degrees which was closer to the recommended spacing of $15 \mathrm{~cm}$.

\section{Germination}

For mechanical planter, it was observed that the observed values for highest and lowest germination percentage were 96.2 and $88 \%$, respectively. The germination percentage decreased as the forward speed increased, while with angle of inclination it increased initially from 30 to 35 degrees and decreased thereafter. Whereas for electronic planter, it was observed that the highest and lowest germination percentages observed were 96.5 and 91.8 respectively. The germination percentage was observed to be decreased as the forward speed increased. While with angle of inclination it was increased from 30 to 35 degrees and decreased thereafter (Table 4).

\section{Seed rate}

For mechanical planter, it was observed that the seed rate data at selected variables is presented (Table 4). The highest and lowest seed rates observed were 24.20 and 21.5 $\mathrm{kg} / \mathrm{ha}$ respectively. The observed seed rate at optimum forward speed and inclination was $22.17 \mathrm{~kg} / \mathrm{ha}$. Whereas for electronic planter, it was observed that the At an optimum forward speed of $2.0 \mathrm{~km} / \mathrm{h}$ and inclination of 35 degrees, a seed rate of $20.17 \mathrm{~kg} / \mathrm{ha}$ was observed which was closer to the recommended seed rate of $20 \mathrm{~kg} / \mathrm{ha}$ (Table 5).

\section{Comparison of mechanical and electronically metered sowing methods}

The comparison o of two methods was done in terms of seed rate, spacing and seed placement index The observe seed rate, spacing and seed placement index values of mechanical and electronic methods were 22.7 $\mathrm{kg} / \mathrm{ha}, 14.4 \mathrm{~cm}$ and $74.3 \%$ and $19.97 \mathrm{~kg} / \mathrm{ha}$, $14.8 \mathrm{~cm}$ and $86.39 \%$, respectively. A saving of $12.04 \%$, in seed rate was observed by sowing with electronic metering method over mechanical. The variation in spacing was less than $4.0 \%$ as compared to mechanical method of sowing. The seed placement index was found to increase by $16.3 \%$ with electronic metering. Thus based on the results of seed rate, spacing and seed placement index it is imperative to say that electronic metering leads to better precision as compared to mechanical sowing (Table 6). 


\section{Cost economics of developed prototype precision paddy planter}

The cost of operation of the tractor drawn prototype precision planter was computed. The final cost of the prototype, the total cost of operation per hour and cost of operation per hectare were determined. The break -even point (BEP) and payback period (PBP) of developed planter were also estimated (IS standard IS: 9164-1979). The cost of electronic was higher than the mechanical due to incorporation of electronic set up. However, keeping the saving in seed in view, the economical advantages are more with electronic as compared to mechanical. The payback period was not found to vary much between the two as only difference of 0.2 years or nearly 3 months was observed (Table 7).

The Seed Placement Index (SPI) and percentage of one and two seeds per hill, increased up to a forward speed of $2.0 \mathrm{~km} / \mathrm{h}$ and 35 degrees angle of inclination and thereafter decreased significantly.

The speed synchronization based electronic metering mechanism was found to lead a saving of $12.04 \%$ in seed rate, $16.3 \%$ increase in seed placement index, spacing closer to recommended spacing with a variation difference of 4 as compared to mechanical planter.

The breakeven point and payback period of developed precision planter was $95 \mathrm{~h} / \mathrm{year}$ and 2.5 years respectively; very close to that of mechanical planter for which the values were $88 \mathrm{~h} /$ year and 2.3 years respectively.

\section{References}

Bamgboye, I A. and Mofolasayo, A. 2006. Performance evaluation of a two-row Okra planter. Agricultural Engineering
International: the CIGR Ejournal, Manuscript PM 06 002. 8:1-10 FAO.2015. Rice market monitor. 18(2):1-29.

FAO STAT. 2011. FAO Statistical databases. FAO. 2015. Rice market monitor. 18(2):1-29. IS- 9164-1979: Guide for estimating cost of Farm Machinery operation. Indian standards institution Govt. of India, New Delhi.1-17.

Kachman, S D. and Smith, J A. 1995. Alternative measures of accuracy in plant spacing for planters using single seed metering. Transactions of the ASAE., 38(2): 379-387

Mahajan, G. Saradana, V. Brar, A S. and Gill, M S. 2005.Grain yield comparison among rice (Oryza sativa L.) varieties under direct seeding and transplanting. Haryana Journal of Agronomy, 20 (1): 68-70.

Pandey, S. and Velasco, L. 2002. Economics of direct seeding in Asia: patterns of adoption and research priorities. International Rice Research Notes 24:2.

Pathak, H. Tewari, A N. Sankhyan, S. Dubey, D S. Mina, U. Singh, V K. Jain, andN Bhatia, A. 2011. Direct-seeded rice: Potential, performance and problems A review. Current Advances in Agricultural Sciences, 3(2): 77-88.

RNAM. 1995. RNAM test codes and procedures for farm machinery / Economic and Social Commission for Asia and the Pacific, Regional Network for Agricultural Machinery.

Sahoo, P K. Pradhan, S C. and Das, D K. 1994. Development and testing of a power-operated pre-germinated Cuban paddy seeder. Agricultural Mechanization in Asia, Africa and Latin America, 25(1):21-24.

Shrivastava, A. K. Jain, S K. Dubey, A K. and Singh, V C. 2003. Performance evaluation of tractor drawn six row 
inclined plate planter for oilseed and pulses. JNKVV Res. J., 37, 72-75.

Singh, S., 1984. Design development and evaluation of tractor drawn ridger planter for winter maize. Biennial Report, Dept. of Farm Power and Machinery, PAU, Ludhiana, India.

Singh, T P. and Mane D M. 2011 Development and laboratory performance of an electronically controlled metering mechanism for okra seed. Agricultural Mechanization in Asia, Africa and Latin America, 42(2): 63-69.

Srigiri, D. Hemanth Reddy, A. Sri Rama Satish, P. Sai, A. and HariBabu, B. 2013. Case study on direct sowing of paddy in selected mandals of Guntur district. B. Tech Thesis. College of Agricultural Engineering, Acharya N G Ranga Agricultural University. Bapatla Andhra Pradesh, India.

Srivastava, A P. and Panwar, JS. 1985. Technology for seeding and planting of paddy. Agricultural Science Progress, 3:13-41.

Wanjura, D F. and Hudspeth, E B. 1969. Performance of vacuum wheels metering individual cottonseed. Transaction of ASAE., 12(6):775-777.

Weerakoon, W.M.W., Mutunayake, M.M.P., Bandara, C., Rao, A. N., Bhandari, D. C., and Ladha, J. K. (2011). Directseeded rice culture in Sri Lanka. Field Crops Res. 121, 53-63.

\section{How to cite this article:}

Rajaiah P., Indra Mani, Adarsh Kumar, Satish D. Lande, Roaf A. Parray, Ashok Kumar Singh and Cini Vergese. 2018. Comparative Study of Mechanical and Electronic Paddy Planter for Direct Seeding. Int.J.Curr.Microbiol.App.Sci. 7(09): 1284-1294. doi: https://doi.org/10.20546/ijcmas.2018.709.153 